\title{
Endoscopic removal of common duct stones: current indications and controversies
}

\author{
R.C. Horton, A. Lauri and J.S. Dooley \\ Academic Department of Medicine, Royal Free Hospital, Pond Street, Hampstead, London NW3 2QG, \\ UK
}

\section{Introduction}

Endoscopic sphincterotomy (ES) is now the method of choice for removing common bile duct stones in most situations. First described 15 years ago, ${ }^{1,2}$ ES, a therapeutic development of endoscopic retrograde cholangiopancreatography (ERCP) has replaced surgical exploration of the common bile ducts. Large series report the success rate and complications of ES. Formal trials, to evaluate the indications for and benefits of this technique, however, have only started to appear recently and some areas of its use remain controversial. This paper reviews the state of the art of ES in current clinical practice. There are few specific contraindications to endoscopic removal of common duct stones (Table I). We shall discuss ES for stones causing duct obstruction, cholangitis and pancreatitis separately. The efficacy of sphincterotomy in patients with a gall bladder in situ remains controversial. Risk-benefit evaluation has to start with an assessment of complications.

\section{Complications of endoscopic sphincterotomy}

The major complications may be classified as early or late. Early complications include haemorrhage, cholangitis, pancreatitis and perforation. Haemor- rhage is usually self-limiting and rarely serious enough to require transfusion, provided there is no bleeding diathesis. In the largest series of endoscopic sphincterotomies reported in the $\mathrm{UK}^{3}$ the incidence of haemorrhage was $3.9 \%$ with transfusion required in $0.6 \%$. It is probable that the size of sphincterotomy correlates with risk of haemorrhage although no data exist to support this hypothesis. Risks of cholangitis, pancreatitis and perforation were $1.6 \%, 0.9 \%$ and $0.5 \%$ respectively in the Middlesex Hospital series. ${ }^{3}$

Retroperitoneal perforation generally heals spontaneously with conservative treatment. Overall mortality of ES is approximately $1.2 \%$, but it is clear that in higher risk patients it may be greater. Thus, while sphincterotomy may be regarded as less interventional than surgery, it is not without significant morbidity and mortality.

The principle long term complications include stone recurrence and stenosis of the sphincterotomy. One study has assessed stenosis in detail. Rosseland and Solhaug ${ }^{4}$ measured sphincterotomy size prospectively in 68 of 75 patients with a gall bladder in situ. The mean diameter was $12.8 \mathrm{~mm}$. In 11 patients there was a reduction of $20 \%$ in sphincterotomy diameter during a follow-up of up to 5 years but all patients were asymptomatic and

Table I Removal of duct stones by ES

\begin{tabular}{ll}
\hline i. & $\begin{array}{l}\text { Contraindications } \\
\text { No clear contraindication except coagulopathy } \\
\text { Indications }\end{array}$ \\
a) Definite: & $\begin{array}{l}\text { Acute obstructive suppurative cholangitis } \\
\text { Acute cholangitis }\end{array}$ \\
& $\begin{array}{l}\text { Duct stones after cholecystectomy } \\
\text { Duct stones in elderly patients (gall bladder in situ) } \\
\text { b) Probable: }\end{array}$ \\
c) Controversial: & $\begin{array}{l}\text { Acute pancreatitis } \\
\text { Duct stones in young patients with gall bladder in } \\
\text { situ }\end{array}$ \\
\hline
\end{tabular}


hence the clinical relevance of this is probably marginal.

Failure of duct clearance occurs in $6 \%$ of cases and patients at particular risk can be identified before the procedure. ${ }^{5}$ Predisposing factors include post-operative strictures, periampullary diverticula, previous Billroth II gastroenterostomy and the presence of large, irregularly shaped, multiple stones. Treatment may be by endoprosthesis, dissolution therapy or lithotripsy. Where a large stone is impossible to remove the risk of subsequent cholangitis is high and endoprosthesis insertion, successful in up to $85 \%$ of patients, is the immediate treatment of choice.

\section{Contraindications to ES and stone removal}

The only clear contraindication to ES is severe coagulopathy. It is generally accepted practice that if the platelet count is less than $70 \times 10^{9} / 1$ or the prothrombin time prolonged by more than 3 seconds, ES should be performed under cover with platelet transfusion or fresh frozen plasma. Alternatively, nasobiliary drainage can be done to relieve obstruction with later elective ES after coagulation status has returned to normal.

\section{Indications for ES and stone removal}

\section{Acute obstructive suppurative cholangitis}

Reynold's pentad (pain, jaundice, fever, confusion and hypotension) is the classical presentation of stone impaction at the ampulla with purulent bile above, under pressure. This is a medical emergency. Appropriate antibiotic therapy (aminoglycoside, ureidopenicillin and metronidazole) is given and followed by emergency biliary decompression. Although no controlled trials of ES versus percutaneous drainage or surgery exist, the results of $E^{6}$ are superior to other techniques and ERCP with ES and stone removal is the treatment of choice.

\section{Acute cholangitis}

Gall stones are the cause of cholangitis in over $80 \%$ of cases. Leese et al. $^{7}$ have now reported a retrospective series of 81 patients with gallstonerelated cholangitis and have clearly shown both the efficacy and safety of endoscopic sphincterotomy as initial management. Comparing sphincterotomy with surgery both complications (27.9 vs $57.1 \%)$ and mortality 4.7 vs $21.4 \%$ ) were significantly lower using an endoscopic approach.

Empyema of the gall bladder following sphincterotomy for cholangitis occurs in approximately
$5 \%$ of cases and particularly in those with an obstructed cystic duct. This risk is minimized by ensuring adequate biliary decompression combined with prolonged antibiotic cover. ${ }^{8}$ Despite this complication, long term follow-up demonstrates the safety of bile duct clearance by ES alone, only $7.0 \%$ requiring later cholecystectomy. ${ }^{8}$ Thus, endoscopic sphincterotomy provides the definitive therapy for acute cholangitis although corroborative prospective data would be valuable.

\section{Duct stones without cholangitis}

The two most important factors in planning treatment of these patients are, first, the general fitness of the patient to undergo surgery and second, the presence or absence of the gall bladder.

Endoscopic sphincterotomy is generally regarded as the treatment of choice for elderly patients with accompanying medical risk factors who are consequently unfit for general anaesthesia, independent of whether they have had a previous cholecystectomy. Overall, clearance rates of $85-90 \%$ are common. However, this group remains at particularly high risk from ES, with a recent series reporting an overall mortality of $11.3 \%{ }^{8}$ The need for successful drainage of the biliary tree has been emphasized in this group of 106 patients with the gall bladder in situ. complication rate of $30.4 \%$ was reported in those with failed drainage compared with $11.7 \%$ whe the duct was cleared. This was a highly significant difference.

In younger patients with a previous cholecystectomy, an endoscopic procedure is appropriate rather than surgical exploration on the basis of lower mortality and morbidity, albeit based on studies in older patients. ${ }^{9-12}$

The management of young, fit patients with a gall bladder in situ is as yet unclear with little published data to go on. Reported studies are retrospective reviews of heterogeneous populations of patients - no randomized controlled trials have been described although they are under way. Can the existing published data give any guidelines?

Table II summarizes the published data on a predominantly elderly population group and gives a brief meta-analysis. ${ }^{4,8,13-25}$ Procedural success is over $90 \%$ and common bile duct clearance approximately $72-100 \%$. Complication rates are seen in about $10 \%$ of this group and mortality is variable. Clearly these patients - mainly elderly - would be at greater risk than younger patients whether ES or surgery is performed. Later cholecystectomy is needed in approximately $10 \%$ of patients indicating that successful clearance of the common duct alone is sufficient treatment for most patients. These data confirm the efficacy of ES alone in this predominantly elderly group. 
Table II Retrospective studies of endoscopic sphincterotomy for common duct stones with gall bladder in situ

\begin{tabular}{|c|c|c|c|c|c|c|c|c|}
\hline Study & Number & $\begin{array}{c}\text { Mean } \\
\text { age } \\
\text { (years) }\end{array}$ & $\begin{array}{c}\text { Mean } \\
\text { follow-up } \\
\text { (months) }\end{array}$ & $\begin{array}{c}\text { Procedure } \\
\text { success } \\
(\%)\end{array}$ & $\begin{array}{c}C B D \\
\text { clearance }(\%)\end{array}$ & $\begin{array}{c}\text { Total } \\
\text { complication } \\
\text { rate }(\%)\end{array}$ & $\begin{array}{c}\text { Early } \\
\text { mortality } \\
(\%)\end{array}$ & $\begin{array}{c}\text { Late } \\
\text { cholecystectomy } \\
(\%)\end{array}$ \\
\hline Cotton $^{13}$ & 71 & 72 & 19 & 99 & 86 & 8.5 & 1.4 & 10.4 \\
\hline Cotton $^{14}$ & 118 & 78 & 40 & - & - & 5.9 & 0 & 5.3 \\
\hline Escourrou $^{15}$ & 234 & 79 & 22 & 92 & 72 & - & - & 5.3 \\
\hline Solhaug ${ }^{16}$ & 22 & 74 & 28 & 95 & 82 & 18.2 & 0 & 18.2 \\
\hline $\operatorname{Moss}^{17}$ & 33 & 72 & 15 & 91 & 77 & 15.2 & 6.6 & 9.5 \\
\hline Duron $^{18}$ & 33 & 83 & 1 & 94 & 76 & 0 & 6.1 & - \\
\hline Tanaka $^{19}$ & 162 & 69 & 36 & - & - & 10 & 0.6 & 3.2 \\
\hline Martin $^{20}$ & 81 & 76 & 24 & 99 & 86 & 7.5 & 1.2 & 6.1 \\
\hline Rosseland ${ }^{4}$ & 75 & 77 & $5-8$ years & 100 & 95 & 13.3 & 2.7 & 15 \\
\hline Davidson $^{8}$ & 106 & 79 & 30 & 99 & 81 & 19.8 & 4.7 & 7.0 \\
\hline Siegel $^{21}$ & 1272 & 73 & $8-13$ years & 100 & - & 14.6 & 0.15 & 8.5 \\
\hline Miller $^{22}$ & 54 & 75 & 28 & - & 89 & 9.0 & 3.7 & 21 \\
\hline Worthley ${ }^{23}$ & 20 & 80 & 8 & 100 & 100 & - & 0 & 30 \\
\hline Hansell ${ }^{24}$ & 121 & 80 & 24 & 100 & 96 & 4.1 & 5 & 18 \\
\hline Ingoldby $^{25}$ & 186 & 80 & 32 & 99 & 93 & 4.8 & 1.6 & 9.6 \\
\hline Total & 2588 & 76 & 34 & 97 & 86 & $10.1^{*}$ & 2.4 & 11.9 \\
\hline
\end{tabular}

CBD - common bile duct; *Including cholecystitis (1.2\%).

The extension of sphincterotomy to a younger population with gall stone disease remains an untested idea, the chief concern being the lack of data on the natural history of biliary tract problems following ES. Nevertheless, as Cotton has written . . . 'few would advise (sphincterotomy) for fit patients under the age of 60 years; the expectation of life is substantial, and the risk of long term complication is much greater . . . further data would clarify the situation; randomized studies would be welcome but are difficult to mount'. ${ }^{26}$

The place of ES followed by elective cholecystectomy versus surgery alone remains an open question. Theoretically, the mortality of surgical common duct exploration is higher than sphincterotomy $(2-8 \%$ vs $1 \%)$ and so use of ES to clear ducts before cholecystectomy would be expected to improve outcome. The first prospective randomized study to test this hypothesis was reported by Neoptolemos et al. ${ }^{27}$ In a study of 115 patients with known common duct stones, there was no significant difference in major $(16.4 \% v s ; 8.5 \%)$ and minor $(16.4 \%$ vs $13.6 \%)$ complication rates between surgical and ES groups. This study has been criticized however for excluding the most ill patients who might have shown particular benefit from sphincterotomy. ${ }^{28}$ However, Heinerman et $a l .^{29}$ have recently reported a prospective nonrandomized study of 728 patients. Preoperative ES reduced the post-operative complication rate from $21.8 \%$ to $2.1 \%$ and mortality from 3.8 to $1 \%$. Unfortunately, no statistical analysis of their data was given. A long term, prospective clinical trial of
ES alone versus ES or surgical removal of common duct stones followed by cholecystectomy would be difficult to perform, but is the only way forward for this controversial issue.

Despite all precautions some patients have retained duct stones after cholecystectomy. If a T-tube has been inserted in the bile duct, is of sufficient size $(>14 \mathrm{FG})$ and can be left long enough to form an adequate tract (greater than 4 weeks) then the percutaneous trans-T-tube tract approach can be used for stone removal. This technique has a lower complication rate than ES and is the method of choice. Often, however, the diameter of the T-tube inserted is too narrow to allow this approach and ES is indicated.

\section{Acute pancreatitis}

Gallstones are the most frequent ( $50 \%)$ underlying cause of acute pancreatitis in the UK. Mortality in this group is approximately $10 \%$ and it is hypothesized that the cause of the pancreatitis is gallstone impaction at the junction of the pancreatic and common bile ducts. Circumstantial support for this finding is provided by the fact that stones are found in the bile ducts in up to $60 \%$ of patients with pancreatitis but the incidence falls as the pancreatitis subsides. ${ }^{30}$ However, it is not known whether the continued presence of gallstones is responsible for progression of an attack from mild to severe. Would all patients benefit from endoscopic decompression of the biliary tract or are there particular high risk groups? 
Having confirmed the safety of sphincterotomy in 107 patients with gallstone pancreatitis ${ }^{31}$ Neoptolemos et al. reported a prospective randomized trial in 121 patients who received either sphincterotomy within 72 hours of admission or conventional resuscitative treatment only. ${ }^{32}$ They stratified patients within 48 hours of admission into mild or severe groups based on the modified Glasgow criteria $^{33}$ and found that complications (particularly respiratory and heart failure, pseudocysts and pleural effusions), mortality and length of hospital stay were significantly lower in the group having ES. Moreover, there were no procedure-related complications in this group. It would therefore appear that early sphincterotomy may be the treatment of choice in severe gallstone pancreatitis. This represents approximately $25 \%$ of all admissions for pancreatitis. ${ }^{32}$ However, opinions differ as to exactly which patients should receive ERCP and ES since there is a high rate of spontaneous recovery. ${ }^{34}$

\section{Failed endoscopic removal of common duct stones: options}

Failure to clear the common duct occurs in only $10 \%$ of cases following successful ES. The principle reasons for failure of duct clearance will be that stones are too large $(>1.5 \mathrm{~cm})$ or too numerous. The main adjuvant treatments available are lithotripsy, dissolution therapy and stenting.

Mechanical lithotripsy (stone crushing) has a role $^{35}$ but is now being supplemented by extracorporeal shock wave techniques and lasers. Shock wave lithotripsy may be most appropriate for large stones ${ }^{36,37}$ with clearance rates of up to $86 \%$ and may become the treatment of choice where available. Pulsed laser lithotripsy also has potential using an endoscopically placed laser fibre. ${ }^{38}$ Complications appear minimal to date but the potential for tissue damage requires a time consuming and sophisticated system to prevent tissue contact.

Dissolution therapy with methyltertbutyl ether, though successful, ${ }^{39}$ again requires technically demanding systems of delivery and its widespread application will be limited.

Endoprosthesis insertion is quick, usually easy and prevents subsequent duct obstruction and sepsis. Early studies demonstrating the feasibility of stents ${ }^{40}$ have now been followed by larger studies $^{41}$ which show successful drainage of the biliary tract in over $90 \%$ of cases with a 1 to 5 year follow-up.

\section{Risk factor assessment in patients undergoing ES}

With these expanding indications for ES, is there any way of identifying preprocedural risk factors which would help the (referring) clinician to choose the best approach for a particular patient?

Neoptolemos et al. ${ }^{42}$ have shown that only serum bilirubin and albumin were of independent significance in predicting morbidity after ES. Medical conditions were not predictive of risk. Interestingly, they identified ES itself as a risk factor for complications after surgery. This group advocates further non-surgical procedures when possible, rather than operation, if there are ESrelated complications.

In elderly patients with gall bladders in situ there is a risk of cholecystitis and empyema after ES for duct stones. Davidson et al. ${ }^{8}$ reported that the only factor predicting complications was the presence of pre-existing cholangitis. This emphasizes the requirement for complete clearance of duct stones as discussed above. Furthermore, non-filling of the gall bladder at cholangiography, implying an obstructed cystic duct, is associated with persisten symptoms and raised mortality. ${ }^{23}$ However, patieu numbers are small in this study and are nof. supported by other, larger series. ${ }^{8}$

\section{Conclusion}

Endoscopic removal of common bile duct stones is now a routine procedure available in many district general hospitals as well as teaching centres. In general, it is the procedure of choice to remove common duct stones in the elderly and those with cholangitis. ERCP and ES is probably appropriate in patients with severe pancreatitis, particularly when not resolving. Retrospective analysis, however, reveals areas of considerable uncertainty, for example, its use in younger patients with intact gall bladders. Therapeutic ERCP carries with it complications and further effort is needed to precisely define risk factors for ES. Prospective studies of stone number and size, sphincterotomy diameter, non filling gall bladder, pre-existing cholangitis and $\sigma$ laboratory criteria are difficult, but are needed to $N$ improve the management and outcome of patients N with common bile duct stones. 


\section{References}

1. Kawai, K., Akasaka, Y., Murakami, K., Tada, M., Kohli, Y. \& Nakajima, M. Endoscopic sphincterotomy of the ampulla of Vater. Gastrointest Endosc 1974, 20: 148-151.

2. Classen, M. \& Demling, L. Endoskopische Sphinkterotomie der papilla Vateri und Steinextraktion aus dem Ductus choledochus. Dtsch Med Wochenschr 1974, 99: 496-497.

3. Vaira, D., D'Anna, L., Ainley, C. et al. Endoscopic sphincterotomy in 1000 consecutive patients. Lancet 1989, ii: 431-434.

4. Rosseland, A.R. \& Solhaug, J.H. Primary endoscopic papillotomy in patients with stones in the common bile duct and gall bladder in situ: a 5-8 year follow up study. World J Surg 1988, 12: $111-116$

5. Siegel, J.H. \& Yatto, R.P. Biliary endoprosthesis for the management of retained common bile duct stones. Am J Gastroenterol 1984, 79: 50-54.

6. Lai, E.C.S. Management of severe acute cholangitis. $\mathrm{Br} J$ Surg 1990, 77: 604-605.

7. Leese, T., Neoptolemos, J.P., Baker, A.R. \& Carr-Locke, D.L. The management of acute cholangitis and the impact of endoscopic sphincterotomy. Br J Surg 1986, 73: 988-992.

8. Davidson, B.R., Neoptolemos, J.P. \& Carr-Locke, D.L. Endoscopic sphincterotomy for common bile duct calculi in patients with gall-bladder in situ considered unfit for surgery. Gut 1988, 29: 114-120.

9. Vellacott, K.D. \& Powell, P.H. Exploration of the common bile-duct: a comparative study. Br J Surg 1979, 66: 389-391.

10. Doyle, P.J., Ward-McQuaid, J.N. \& Smith, A.M. The value of routine per-operative cholangiography - a report of 4000 cholecystectomies. Br J Surg 1982, 69: 617-619.

11. Cotton, P.B. Endoscopic management of bile duct stones. Gut 1984, 25: 587-597.

12. Crumplin, M.K.H., Jenkinson, L.R., Kassab, J.Y., Whitaker, C.M. \& Al-Boutahi, F.H. Management of gall stones in a district general hospital. Br J Surg 1985, 72: 428-432.

13. Cotton, P.B. \& Vallon, A.G. Duodenoscopic sphincterotomy for removal of bile duct stones in patients with gall bladders. Surgery 1982,-91: 628-630.

14. Cotton, P.B. 2-9 year follow-up after sphincterotomy for stones in patients with gall bladders. Gastrointest Endoscopy 1986, 32: 157 (abstract).

15. Escourrou, J., Cordova, J.A., Lazorthes, F., Frexinos, J. \& Ribet, A. Early and late complications after endoscopic sphincterotomy for biliary lithiasis with and without the gall bladder in situ. Gut 1984, 25: 598-602.

16. Solhaug, J.H., Fokstuen, O., Rosseland, A. \& Rydberg, B. Endoscopic papillotomy in patients with gall-bladder in situ. Acta Chir Scand 1984, 150: 475-478.

17. Moss, J.G., Saunders, J.H. \& Wild, S.R. Endoscopic papillotomy for removal of common bile duct stones without cholecystectomy. $J$ R Coll Surg (Edin) 1985, 30: 112-114.

18. Duron, J.J., Roux, J.M., Imbaud, P., Dumont, J.L., Dutet, D. \& Validire, J. Biliary lithiasis in the over 75 age group: a new therapeutic strategy. Br J Surg 1987, 74: 848-849.

19. Tanaka, M., Ikeda, S., Yoshimoto, H. \& Matsumoto, S. The long term fate of the gall bladder after endoscopic sphincterotomy. Am J Surg 1987, 154: 505-509.

20. Martin, D.F. \& Tweedle, D.E.F. Endoscopic management of common duct stones without cholecystectomy. $\mathrm{Br}$ J Surg 1987, 74: 209-211.

21. Siegel, J.H., Safrany, L., Ben-Zui, J.S. et al. Duodenoscopic sphincterotomy in patients with gall bladders in situ: report of a series on 1272 patients. Am J Gastroenterol 1988, 83: 1255-1258

22. Miller, D.M., Kozarek, R.A., Ryan, J.A., Ball, T.J. \& Traverso, L.W. Surgical versus endoscopic management of common bile duct stones. Ann Surg 1988, 207: 135-141.
23. Worthley, C.S. \& Toouli, J. Gall bladder non-filling: an indication for cholecystectomy after endoscopic sphincterotomy. Br J Surg 1988, 75: 796-798.

24. Hansell, D.T., Millar, M.A., Murray, W.R., Gray, G.R. \& Gillespie, G. Endoscopic sphincterotomy for bile duct stones in patients with intact gallbladders. Br J Surg 1989, 76: 856-858.

25. Ingoldby, C.J.H., El-Saadi, J., Hall, R.I. \& Denyer, M.E. Late results of endoscopic sphincterotomy for bile duct stones in elderly patients with gall bladders in situ. Gut 1989 , 30: $1129-1131$

26. Cotton, P.B., Invited commentary. World J Surg 1988, 12: 115-116.

27. Neoptolemos, J.P., Carr-Locke, D.L. \& Fossard, D.P. Prospective randomised study of preoperative endoscopic sphincterotomy versus surgery alone for common bile duct stones. Br Med J 1987, 294: 470-474.

28. Cotton, P.B. Preoperative endoscopic sphincterotomy as an adjunct to cholecystectomy for common bile duct stones. Hepatology 1988, 8: 191-192.

29. Heinerman, P.M., Boeckl, O. \& Pimpl, W. Selective ERCP and preoperative stone removal in bile duct surgery. Ann Surg 1989, 209: 267-272.

30. Acosta, J.M., Pelligrini, C.A. \& Skinner, D.B. Aetiology and pathogenesis of acute biliary pancreatitis. Surgery 1980, 88: 118-125.

31. Neoptolemos, J.P., London, N., Slater, N.D., Carr-Locke, D.L., Fossard, D.P. \& Moosa, A.R. A prospective study of ERCP and endoscopic sphincterotomy in the diagnosis and treatment of gallstone acute pancreatitis. Arch Surg 1986, 121: 697-702.

32. Neoptolemos, J.P., Carr-Locke, D.L., London, N.J., Bailey, I.A., James, D. \& Fossard, D.P. Controlled trial of urgent ERCP and endoscopic sphincterotomy versus conservative treatment for acute pancreatitis due to gallstones. Lancet 1988, ii: 979-983.

33. Blamey, S.L., Imrie, C.W., O'Neill, J., Gillmour, W.H. \& Carter, D.C. Prognostic factors in acute pancreatitis. Gut 1984, 25: 1340-1346.

34. Zimmon, D. What is the role of endoscopy in the management of biliary pancreatitis and when should it be utilised? Am J Gastroenterol 1990, 85: 9-10.

35. Schneider, M.U., Matek, W., Bauer, R. \& Dumschker, R. Mechanical lithotripsy of bile duct stones in 209 patients: effect of technical advances. Endoscopy 1988, 20: 248-253.

36. Paumgartner, G. Fragmentation of gallstones by extracorporeal shock waves. Semin Liver Dis 1987, 4: 317-321.

37. Sauerbruch, T. \& Stern, M. Study Group for Shock Wave Lithotripsy. Fragmentation of bile duct stones by extracorporeal shock waves. Gastroenterology 1988, 96: 146-152.

38. Ell, C., Lux, G., Hochberger, J., Muller, D. \& Demling, L. Laser lithotripsy of common bile duct stones. Gut 1988, 29; 746-751.

39. Kaye, G.L., Summerfield, J.A., McIntyre, N. \& Dooley, J.S Methyl tert butyl ether dissolution therapy for common bile duct stones. I' Hepatol 1990, 10: 337-340.

40. Cotton, P.B., Forbes, A., Leung, J.W.C. \& Dineen, L. Endoscopic stenting for long term treatment of large bile duct stones: 2 to 5 year follow up. Gastrointest Endosc 1987, 33: $411-412$.

41. Kill, J., Kruse, A., Rokkjaer, M. Large bile duct stones treated by endoscopic biliary drainage. Surgery 1989, 105: 51-56.

42. Neoptolemos, J.P., Shaw, D.E. \& Carr-Locke, D.L. A multivariate analysis of preoperative risk factors in patients with common bile duct stones. Ann Surg 1989, 209: 157-161. 